\title{
Seismic Resilience Evaluation of Urban Buildings Based on FEMA-P58 and Redi
}

\author{
Yongmei $\mathrm{ZHAI}^{\mathrm{a}}$, Xinyun $\mathrm{XU}^{\mathrm{b}, 1}$ and Shenglong $\mathrm{CHEN}^{\mathrm{c}}$ \\ a Shanghai Institute of Disaster Prevention and Relief, Tongji University, Shanghai \\ 200092, China \\ ${ }^{\mathrm{b}}$ College of civil Engineering, Tongji University, Shanghai, 200092, China \\ ${ }^{c}$ Center for Spatial Information Science, at the University of Tokyo, 5-1-5 \\ Kashiwanoha, Kashiwa-shi, Chiba, Japan
}

\begin{abstract}
With the improvement of seismic performance of new buildings, casualties and building collapse caused by earthquakes are effectively controlled, and people pay more attention to the seismic resilience of buildings. A seismic resilience evaluation method for urban buildings was studied in this paper based on FEMA-P58 building loss evaluation method and Redi recoverable evaluation system, and the implementation process of this method was illustrated by taking one reinforced concrete structure and one multi-story masonry structure as examples. The result showed that this method can reasonably evaluate the building resilience, which can provide the research basis for future construction of seismic resilient cities.
\end{abstract}

Keywords. Seismic resilience, FEMA-P58, Redi, dynamic analysis, earthquake loss assessment.

\section{Introduction}

China's current seismic design code[1] adopts the three-level seismic fortification objectives of "No damage under minor earthquake; Repairable under moderate earthquake; No collapse under major earthquake", which is mainly aimed at ensuring the life safety of people in earthquake. However, with the continuous improvement of the seismic performance of new buildings, the casualties and building collapse caused by earthquakes are effectively controlled, but the economic loss caused by the loss of urban functions and reconstruction and restoration is still huge. For example, in the 311 East Japan Earthquake, the economic loss caused by the earthquake was as high as 16.9 trillion yen[2], and the estimated repair cost reached 23 trillion yen[3].

The experience of the East Japan Earthquake shows that even well-designed seismic codes can't completely avoid the risk that entire city will need to be repaired and rebuilt after an earthquake. Therefore, Seismic Resilience, also known as Seismic Recoverability, has become the focus of international seismic engineering in recent years[4-6]. Earthquake resilience not only requires a building to have enough ability to withstand earthquake disasters, but also emphasizes the ability to quickly restore the original function after destruction and maintain the normal operation of the city. For

${ }^{1}$ Corresponding Author, Xinyun XU, College of civil Engineering, Tongji University, Shanghai, 200092, China; Email: 948918704@qq.com. 
densely populated and economically developed urban areas, a reasonable evaluation of seismic resilience can provide important reference information for decision makers, thus helping to reduce economic loss caused by earthquakes and shortening the recovery period of urban functions.

In order to meet the needs of urban seismic resilience evaluation, the Federal Emergency Management Agency (FEMA) issued the FEMA P-58 report "Seismic performance assessment of buildings" in 2012 after long-term research[7-8]. This method is based on an idea of new general performance-based design, which emphasizes more on the "economic performance" of the building, and can directly consider the vulnerability and earthquake loss of each structural and non-structural component of the building. In 2014, based on the FEMA-P58 report, Arup proposed the Redi building recoverability evaluation system[9]. The Redi system completely surpasses the design and evaluation methods of the current code, aiming to achieve better seismic performance of buildings and provide a set of quantitative evaluation method of post-earthquake recoverability for building users.

In this study, a multi-degree of freedom centralized mass shear model was used to conduct nonlinear dynamic analysis to obtain the engineering demand parameters (EDP) and the vulnerability of buildings. The seismic resilience evaluation method of urban buildings based on FEMA-P58 building loss assessment method and Redi recoverability evaluation system was studied. One common reinforced concrete structure and one multi-story masonry structure which are common in cities were taken as examples to introduce the implementation process of the evaluation method in detail.

\section{Evaluation Method}

\subsection{Fema-P58 Earthquake Loss Assessment Method}

The basic principle of FEMA-P58 is based on a performance-based engineering framework, which leads to three types of evaluation: earthquake intensity-based, earthquake scenario-based, and time-based performance evaluation. The performance evaluation method based on earthquake intensity was adopted in this study. The overall process includes five steps, as shown in figure 1. 


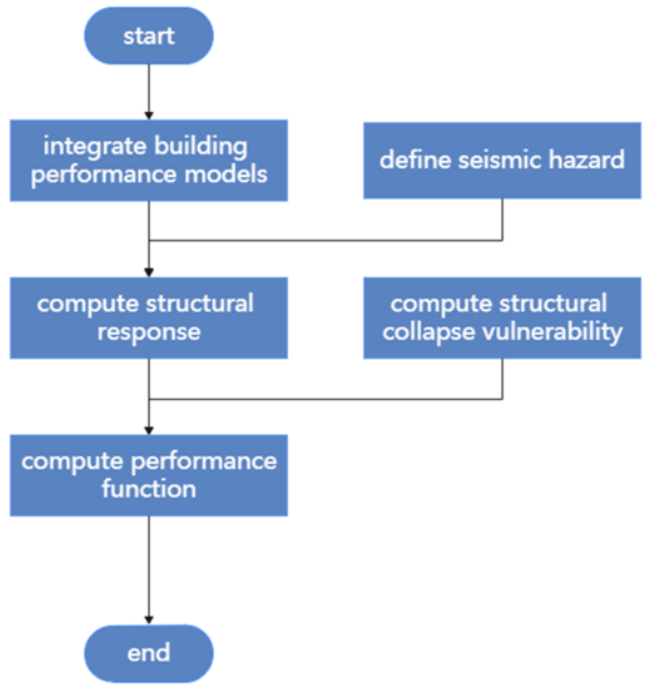

Figure 1. Performance evaluation flow chart based on seismic intensity.

1) establish the integrated performance model

Building performance model is a collection of building information used to calculate earthquake losses of buildings. It contains the basic data, the living conditions and the vulnerable structural components and non-structural components of buildings.

2) define seismic hazard

Seismic hazard is defined by ground motion intensity. For the performance evaluation method based on earthquake intensity, ground motion intensity can be realized according to the user-defined acceleration response spectrum.

3 ) analyze structural response

For predictable damage parameters of structural and non-structural components, structural response analysis can provide an estimated median value of structural demand parameters called engineering demand parameters (EDP). The main EDP includes floor peak acceleration, inter-story drift angle, residual drift ratio and so on. In this study, EDP was obtained by nonlinear time-history analysis.

4) compute structural collapse vulnerability

Collapse vulnerability is defined as the relationship between ground motion intensity and the probability of structural collapse, which can be expressed as a logarithmic normal distribution function related to the spectral acceleration $S_{a}(T)$ corresponding to the first-order period of the structure. The collapse vulnerability function was established by dynamic increment time-history analysis (IDA) in this study.

5) compute structural performance function

In order to take the randomness and variability of the variables into consideration, FEMA P-58 uses the Monte Carlo method to evaluate the seismic performance of buildings. The Monte Carlo method is a highly repetitive process and each iteration is called the "implementation", as shown in figure 2, which represents a possible result of building performance (repair cost, repair time, number of casualties, etc.). After a large quantity of "implementation", the distribution of the performance function can be fitted by estimating the statistical parameters of the population according to the samples. 


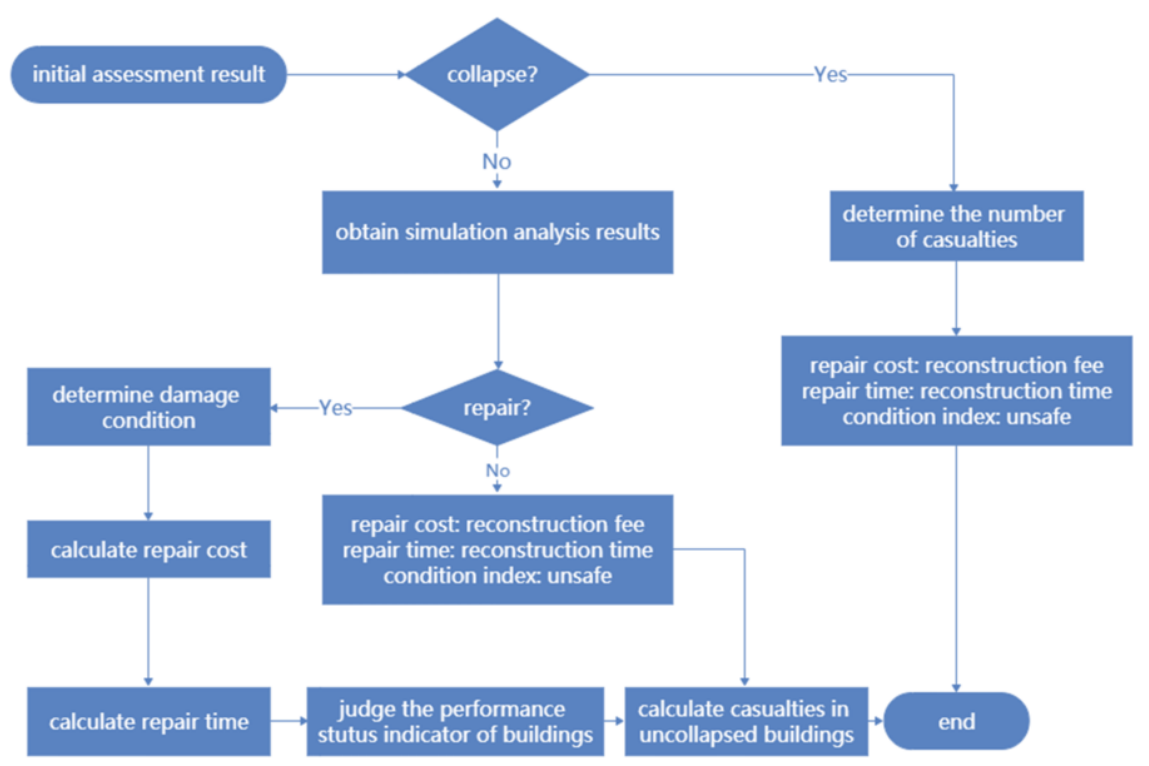

Figure 2. evaluation process of the performance results of an "implementation".

\subsection{Redi Architectural Recoverability Evaluation System}

Redi recoverablility evaluation system established three evaluation levels: Platinum, Gold and Silver, as shown in table 1. The objective of each level is to significantly reduce the seismic risk of code-designed buildings at fortification level. In the table, there are two states of re-occupancy time: Green Tag and Yellow Tag. Green Tag will be given when buildings are deemed safe enough to be used for shelter or reuse; If the building suffers moderate damage that may endanger the lives of the users, it will be inspected by professional personnel and then given a Yellow Tag.

Table 1. Performance objectives of different levels of Redi system.

\begin{tabular}{ccccl}
\hline $\begin{array}{c}\text { Evaluation } \\
\text { level }\end{array}$ & $\begin{array}{c}\text { Re- } \\
\text { occupancy } \\
\text { time }\end{array}$ & $\begin{array}{c}\text { Function } \\
\text { recovery } \\
\text { time }\end{array}$ & $\begin{array}{c}\text { Direct } \\
\text { economic } \\
\text { loss }\end{array}$ & \multicolumn{1}{c}{ Resident security } \\
\hline Platinum & $\begin{array}{c}\text { at once } \\
\text { (Green Tag) }\end{array}$ & $<72 \mathrm{~h}$ & $<2.5 \%$ & $\begin{array}{l}\text { Failure of building } \\
\text { components will not result } \\
\text { in death or injury. }\end{array}$ \\
Gold & $\begin{array}{l}\text { at once } \\
\text { (Green Tag) }\end{array}$ & $<1$ month & $<5 \%$ & $\begin{array}{l}\text { Failure of building } \\
\text { components will not result } \\
\text { in death or injury. }\end{array}$ \\
Silver & $\begin{aligned} \text { Failure of building } \\
\text { components (not structural } \\
\text { collapse) may result in } \\
\text { injury, but not death. }\end{aligned}$ \\
\hline
\end{tabular}

On the other hand, in the economic loss caused by earthquakes, the direct loss includes the demolition and repair costs of the buildings after the earthquake and the restoration costs of the infrastructure, etc., while the greater part is the indirect loss 
caused by the Downtime of the buildings. Downtime refers to the time the building needs to reach the specified state of recovery after an earthquake[10], which is often difficult to quantify. Therefore, based on the building damage condition and maintenance time calculated by FEMA P-58 method, REDI system established the Downtime calculation method for the restoration to the state of reuse and function recovery of the building, as shown in figure 3.

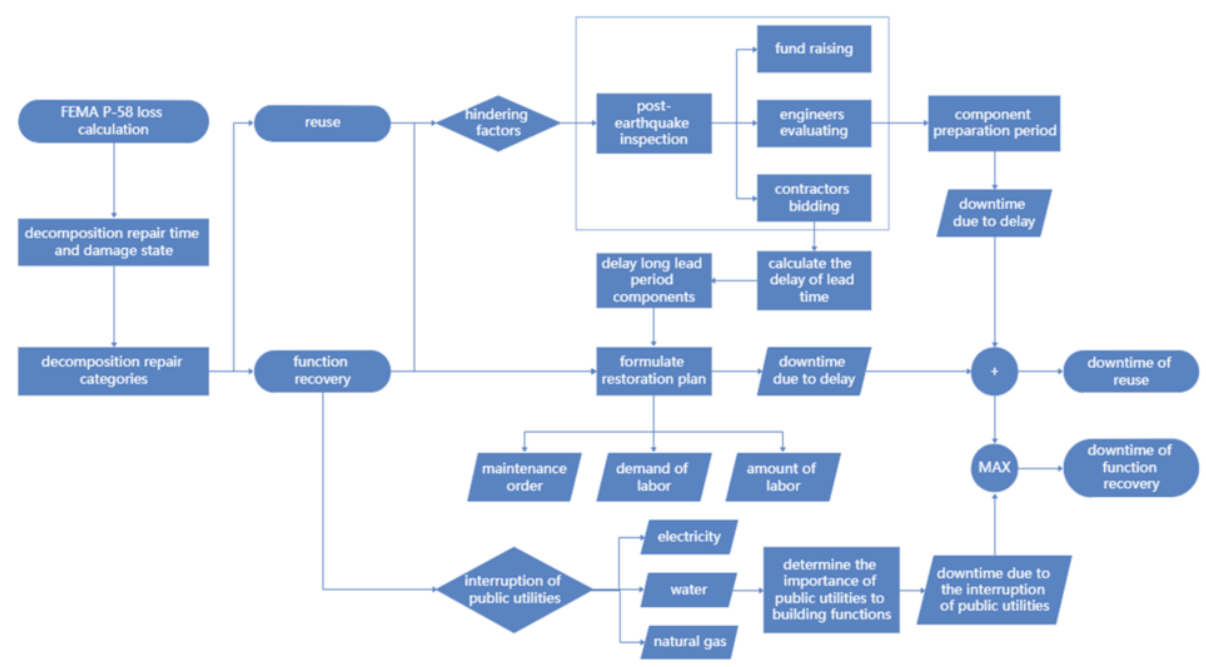

Figure 3. Flow chart of calculating Downtime of buildings by Redi system.

\section{Analysis of Examples}

\subsection{Building Performance Model}

In this study, a reinforced concrete frame office building (Building A) and a multi-story masonry residential building (Building B) in the urban area of Shanghai were selected as examples. The information of structural component was obtained through architectural design drawings (as shown in table 2). The investigation was carried out and the non-structural component and important property data of the building were obtained by combining with FEAM P-58 database, and the performance models of the two buildings were established. The performance group is a class of components with the same seismic demand parameters (such as story drift angle, floor acceleration, etc.) and similar seismic damage modes. The typical component vulnerability database in FEMA P-58 provides vulnerability curves and result functions for a variety of performance groups. The same or similar performance group data can be directly invoked from the database depending on the building condition. For performance groups that are difficult to investigate, such as pipelines, the type and quantity can be estimated according to the standard quantity database of non-structural components provided by FEMA P-58. The performance groups selected for the example buildings are shown in table 3 , and the population model is shown in figure 4 and figure 5 . 
Table 2. Basic information of the example buildings.

\begin{tabular}{ccc}
\hline Name of building & Building A & Building B \\
\hline Structure type & reinforced concrete frame & multi-story masonry \\
Number of floors & 7 & 6 \\
Layer height $/ \mathrm{m}$ & 3.5 & 2.7 \\
Floor area $/ \mathrm{m}^{2}$ & 1036 & 549 \\
Construction time & 1987 & 1952 \\
Service function & office building & residential building \\
Reset cost $(\$ 10000)$ & 1163 & 328 \\
Repair time (day) & 430 & 240 \\
\hline
\end{tabular}

Table 3. Examples' type of building performance group.

\begin{tabular}{|c|c|c|c|}
\hline Component type & Component name & $\begin{array}{c}\text { Vulnerability } \\
\text { category number }\end{array}$ & Directivity $^{\mathrm{a}}$ \\
\hline \multirow{3}{*}{ Structural components } & beam-column joint of & B1041.041 & $\mathrm{D}$ \\
\hline & concrete frame & B1041.042 & $\mathrm{D}$ \\
\hline & masonry bearing wall & $\mathrm{B} 1052.011$ & $\mathrm{D}$ \\
\hline \multirow{6}{*}{$\begin{array}{l}\text { Enclosure } \\
\text { components }\end{array}$} & partition & B2011.201a & $\mathrm{D}$ \\
\hline & window & B2022.001 & $\mathrm{D}$ \\
\hline & partition and & $\mathrm{C} 1011.001$ & $\mathrm{D}$ \\
\hline & decoration & C3011.001 & $\mathrm{D}$ \\
\hline & concrete roof & B3011.011 & $\mathrm{N}$ \\
\hline & concrete floor slab & $\mathrm{C} 3027.001 \mathrm{a}$ & $\mathrm{N}$ \\
\hline \multirow{4}{*}{ Internal facilities } & concrete staircase & C2011.001a & $\mathrm{D}$ \\
\hline & headlight & $\mathrm{C} 3034.001$ & $\mathrm{~N}$ \\
\hline & ceiling & C3032.001 & $\mathrm{N}$ \\
\hline & elevator & D1014.011 & $\mathrm{N}$ \\
\hline \multirow{3}{*}{ Water pipe } & cold water pipe & D2021.011a & $\mathrm{N}$ \\
\hline & hot water pipe & D2022.001a & $\mathrm{N}$ \\
\hline & sewage pipe & D2031.011b & $\mathrm{N}$ \\
\hline \multirow{2}{*}{$\begin{array}{l}\text { Mechanical and } \\
\text { electrical equipment }\end{array}$} & voltage control center & D5012.013a & $\mathrm{N}$ \\
\hline & $\begin{array}{l}\text { low-voltage } \\
\text { switchgear }\end{array}$ & D5012.021a & $\mathrm{N}$ \\
\hline \multirow{4}{*}{ Hvac equipment } & water chilling unit & D3031.021a & $\mathrm{N}$ \\
\hline & air condition pipe & D3041.011a & $\mathrm{N}$ \\
\hline & $\begin{array}{l}\text { air condition } \\
\text { accessories }\end{array}$ & D3041.032a & $\mathrm{N}$ \\
\hline & $\begin{array}{c}\text { variable air volume } \\
\text { system }\end{array}$ & D3041.041a & $\mathrm{N}$ \\
\hline \multirow{3}{*}{ Fire equipment } & $\begin{array}{l}\text { combined air } \\
\text { conditioning unit }\end{array}$ & D3052.011a & $\mathrm{N}$ \\
\hline & fire sprinkler & D4011.021a & $\mathrm{N}$ \\
\hline & office furniture & E2022.001 & $\mathrm{N}$ \\
\hline \multirow{3}{*}{ Others } & bookcase & E2022.102a & $\mathrm{N}$ \\
\hline & computer & E2022.020 & $\mathrm{N}$ \\
\hline & file cabinet & $\mathrm{E} 2022.112 \mathrm{a}$ & $\mathrm{N}$ \\
\hline
\end{tabular}

an directivity, $\mathrm{D}$ indicates that the performance group is directional, and $\mathrm{N}$ indicates that the performance group is non-directional. 


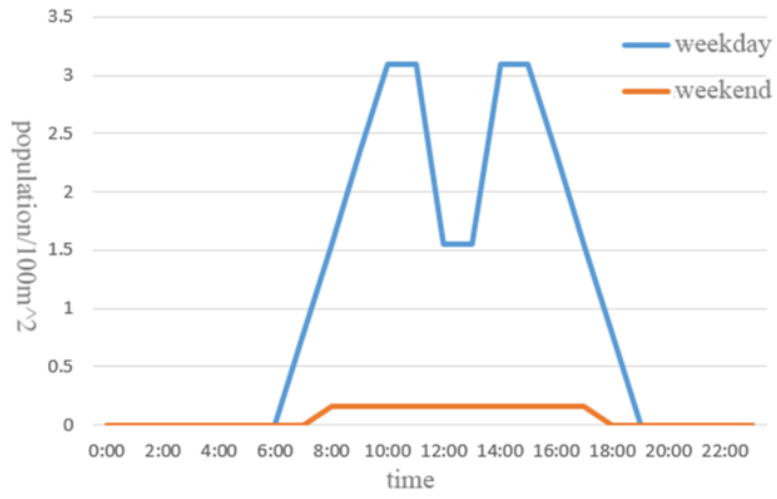

Figure 4. Population models of Building A.

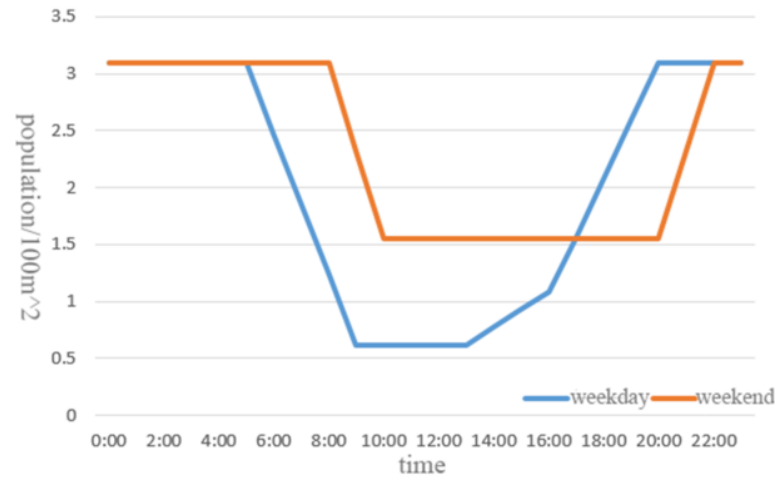

Figure 5. Population models of Building B.

\subsection{Selection of Ground Motion}

In the nonlinear time-history analysis, in order to make a reasonable estimate of the median of the structure response, the FEMA P-58 report suggested that the elastic acceleration response spectrum with a damping ratio of $5 \%$ and the response spectrum acceleration of the basic period should be used to select and modulate the ground motion. Since peak ground acceleration (PGA) is used as the ground motion intensity index in China's seismic code, PGA is also used in this study to represent the ground motion intensity.

According to the small ground motion parameter zoning map[11] of Shanghai and Shanghai building seismic design code (J10284-2013)[12], from the earthquake database of Pacific Earthquake Engineering Research Center (PEER)[13] and the KiKnet digital strong earthquake recording system of Japan's National Research Institute for Earth Science and Disaster Resilience[14] 28 seismic wave data were selected (including 14 frequent and medium earthquakes and 14 rare earthquakes), and the average of the selected ground motion response spectrum are in good agreement with the target response spectrum within the period of $0 \sim 6 \mathrm{~s}$, as shown in figure 6 and figure 7. 


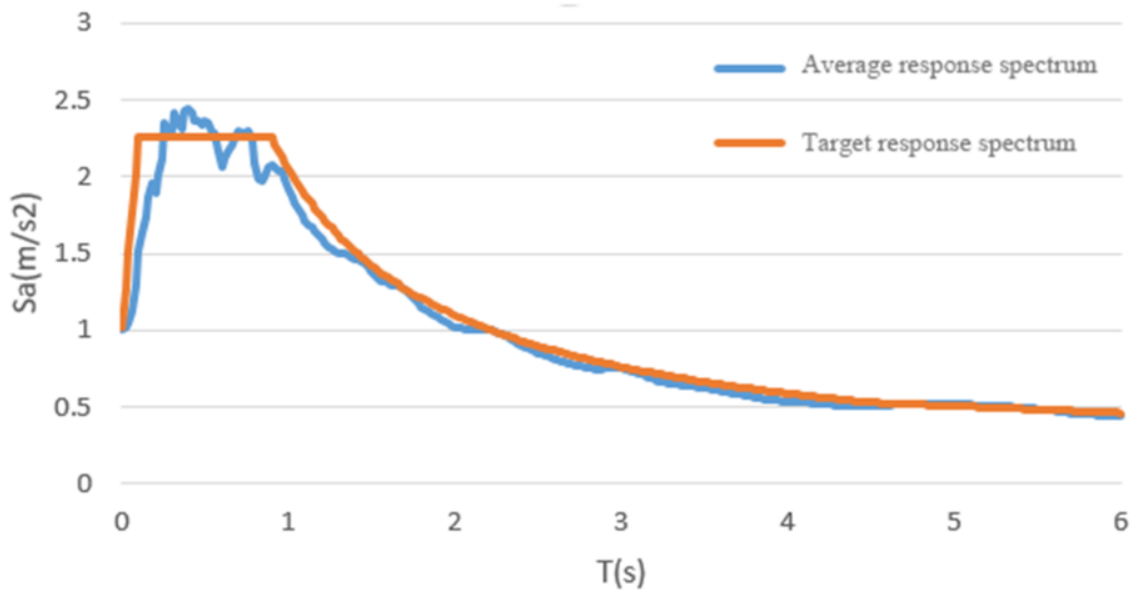

Figure 6. Comparison of seismic wave response spectrum and target response spectrum of medium earthquake.

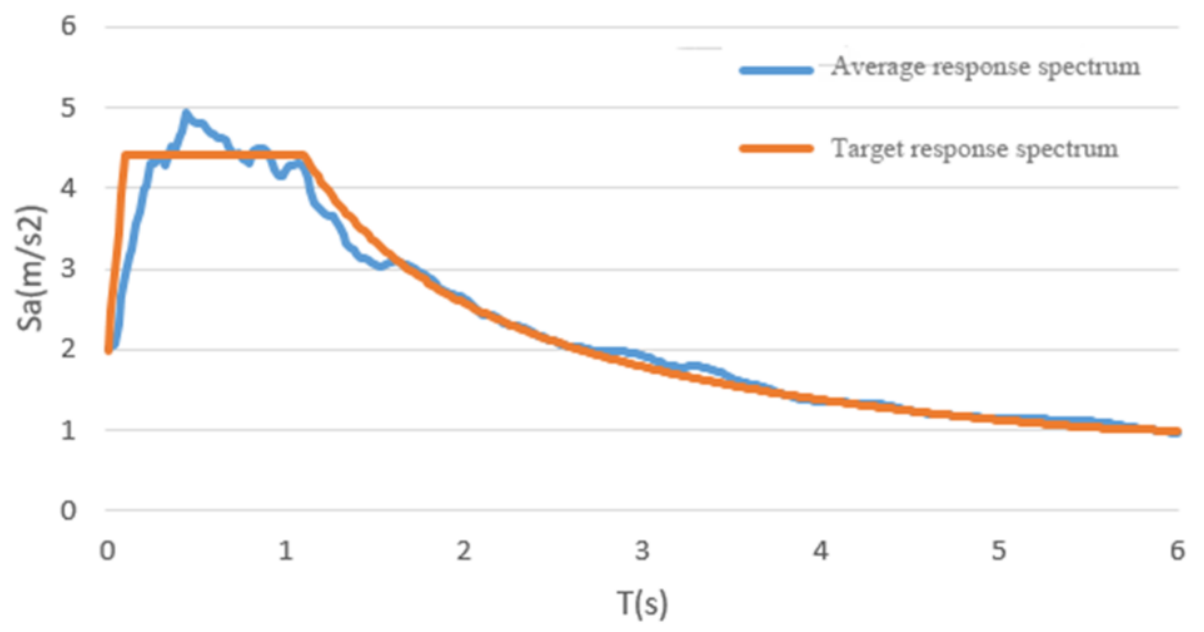

Figure 7. Comparison of seismic wave response spectrum and target response spectrum of rare earthquake.

\subsection{Result of Dynamic Analysis}

In order to quickly obtain the EDP and collapse vulnerability curves of the two buildings, a multi-degree-of-freedom lumped-mass shear model[15] was used for modeling, and nonlinear time-history analysis and IDA analysis were performed in OpenSees 2.50. All parameters of the multi-degree-of-freedom lumped-mass shear model can be determined only by the macro data such as building's structure type, layer height, area, etc., which ensures the calculation accuracy and has high calculation efficiency, so it can be used in the post-earthquake loss assessment of regional buildings[16]. The peak acceleration of the seismic wave selected in Section 2.2 was amplitude modulated to minor, moderate and major earthquake intensity (35 Gal, 100 
Gal and $200 \mathrm{Gal}$ ) to perform dynamic analysis.

Seismic responses of each floor of the two buildings under different earthquake intensities are shown in figure 8 and figure 9. The collapse vulnerability curve parameters (mean value and variance) of example buildings obtained by log-normal distribution fitting are shown in table 4.
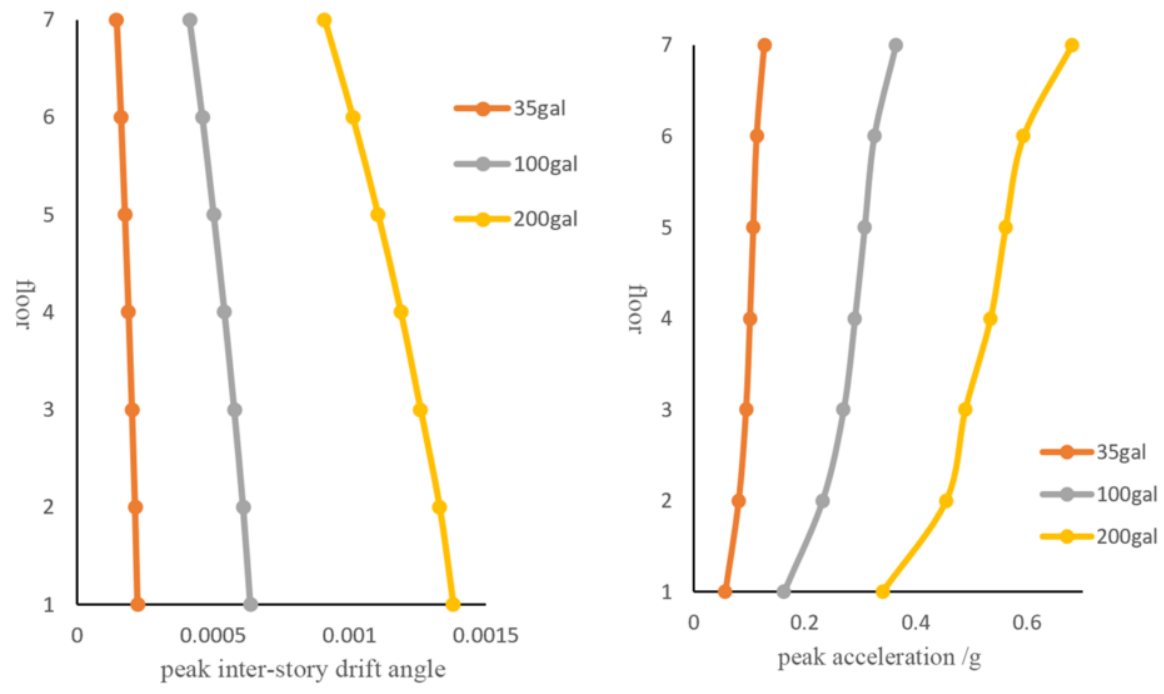

Figure 8. Building A's seismic response under different intensities.
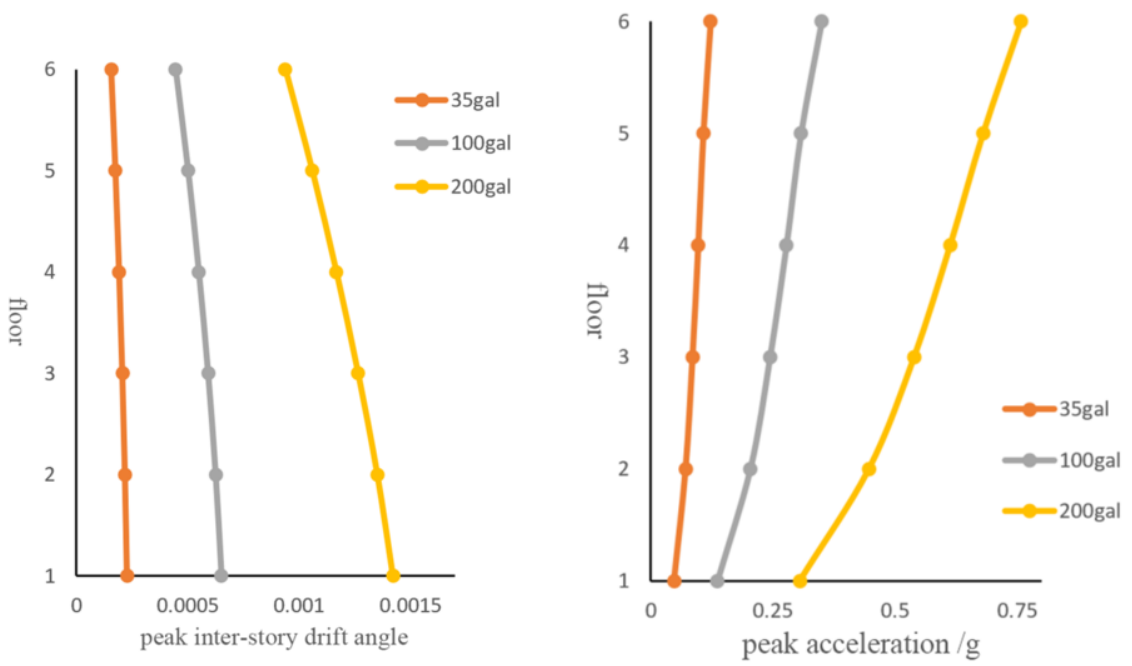

Figure 9. Building B's seismic response under different intensities. 
Table 4. Collapse and repair vulnerability curve parameters of the two buildings.

\begin{tabular}{cccc}
\hline \multicolumn{2}{c}{ Name of building } & $\begin{array}{c}\text { Building } \\
\text { A }\end{array}$ & $\begin{array}{c}\text { Building } \\
\text { B }\end{array}$ \\
\hline Collapse vulnerability & mean value of PGA/g & 1.195 & 0.452 \\
curve & variance & 0.65 & 0.67 \\
\multirow{2}{*}{$\begin{array}{c}\text { Repair vulnerability curve } \\
\end{array}$} & mean value of residual drift & 0.01 & 0.01 \\
& angle & 0.3 & 0.3 \\
\hline
\end{tabular}

\section{Evaluation Results}

\subsection{Assessment Loss Assessment}

The probability distribution curve of the restoration cost of the two buildings under different earthquake intensities is shown in figure 10 and figure 11 , and the mean value of the restoration cost is shown in figure 12 and figure 13. It can be seen that the structural components of Building A are in an elastic state under minor and moderate earthquakes, causing almost no economic losses and the repair cost is mainly caused by the maintenance costs of non-structural components such as partition walls and so on. Under rare earthquakes, the proportion of maintenance cost of structural components increases slightly. On the contrary, the repair costs of building B under the three earthquake intensities are all much higher than that of building A, and the repair cost of structural components is the main one. Apart from the fact that Building B was built earlier, the seismic performance of a multi-story masonry structure is lower than that of a reinforced concrete frame structure.

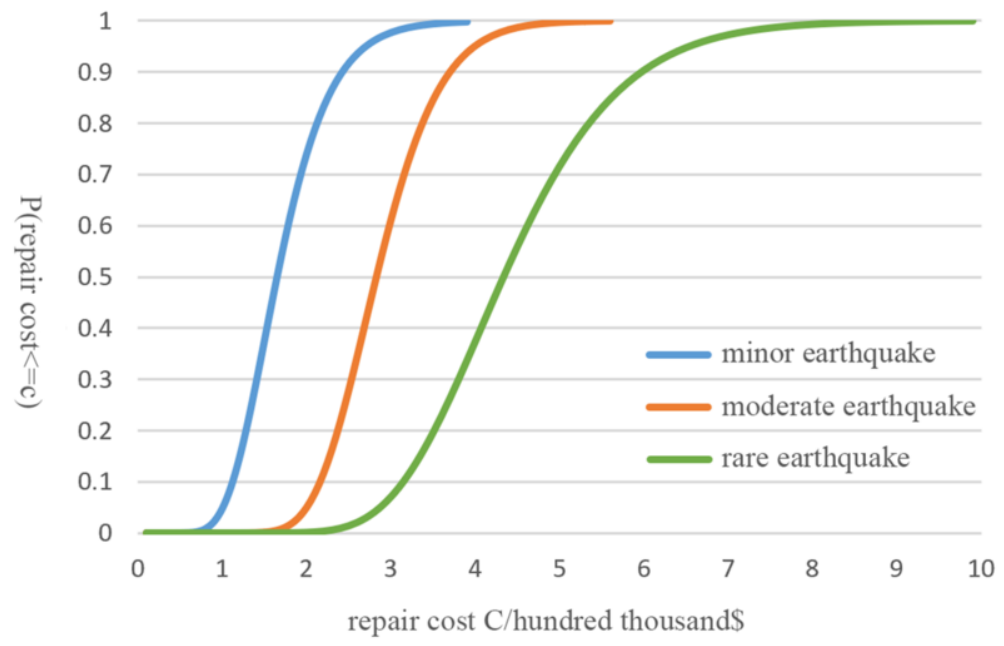

Figure 10. Probability distribution curve of repair cost under different earthquake intensities of Building A. 
1074 Y. Zhai et al. / Seismic Resilience Evaluation of Urban Buildings Based on FEMA-P58 and Redi

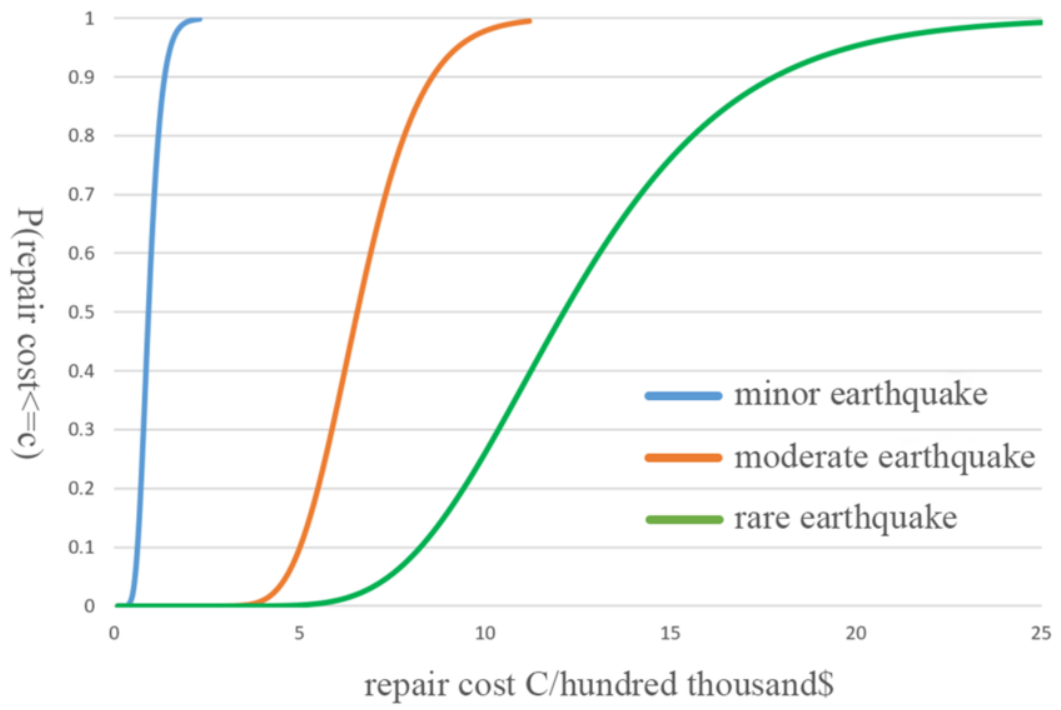

Figure 11. Probability distribution curve of repair cost under different earthquake intensities of Building B.

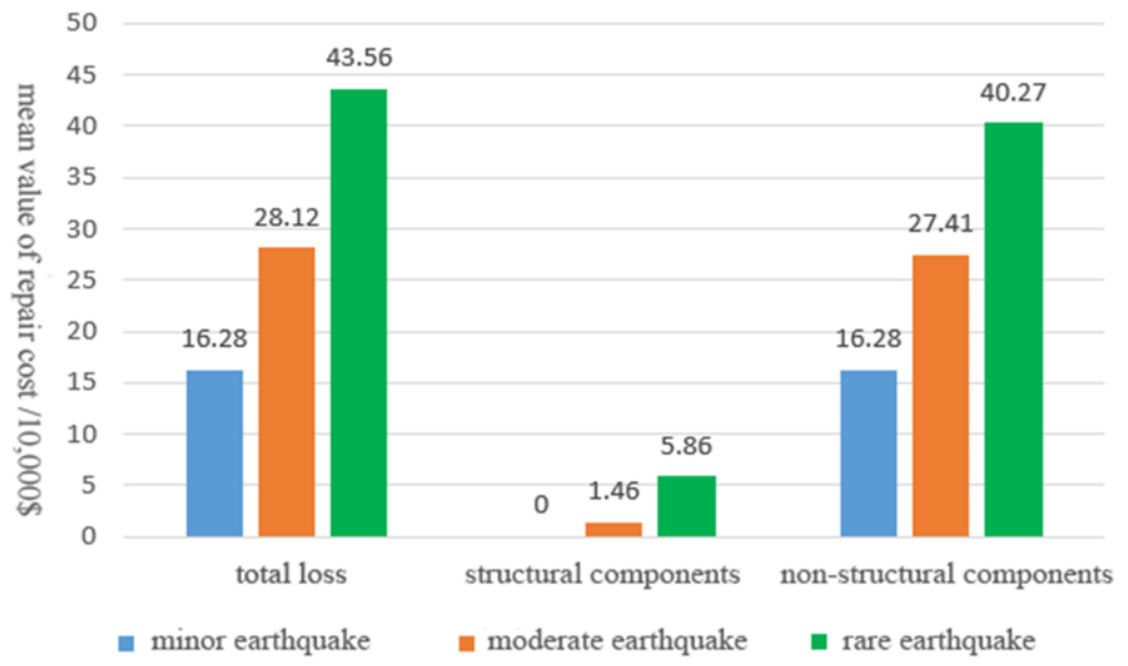

Figure 12. Mean value of repair cost under different earthquake intensities of Building A. 


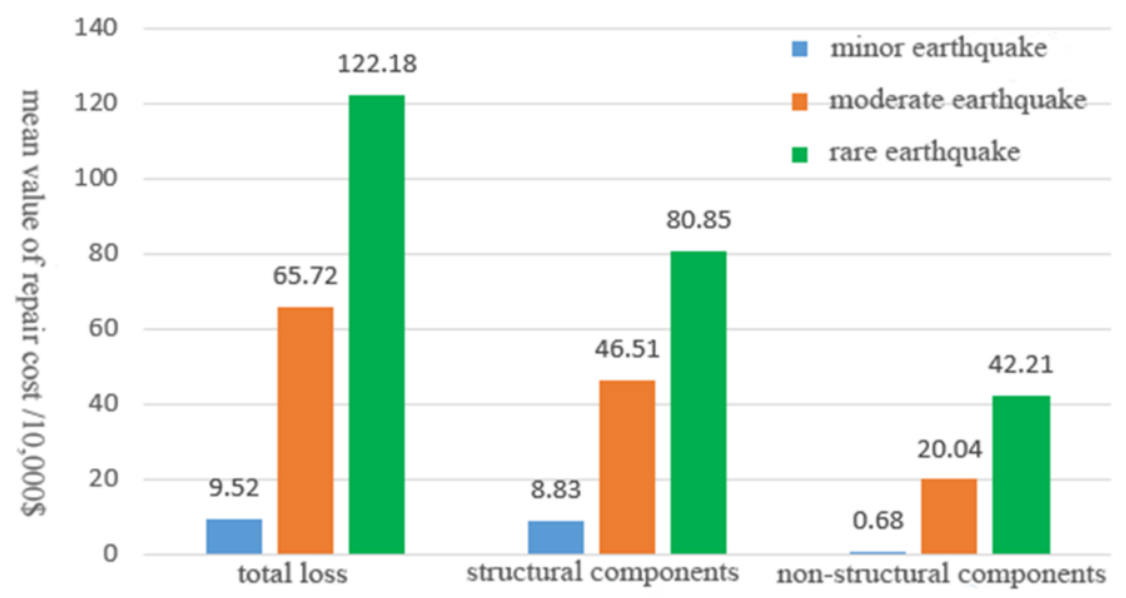

Figure 13. Mean value of repair cost under different earthquake intensities of Building B.

Mean value of repair time under different earthquake intensities of the two buildings is shown in figure 14 and figure 15. Repair time represents the amount of work required to repair the building. Similar to repair cost, the repair time of Building A is dominated by non-structural components, while that of Building B is dominated by structural components. On the one hand, this is due to the large proportion of the loss of structural components, and on the other hand, the repair time of structural components is generally longer than that of non-structural components.

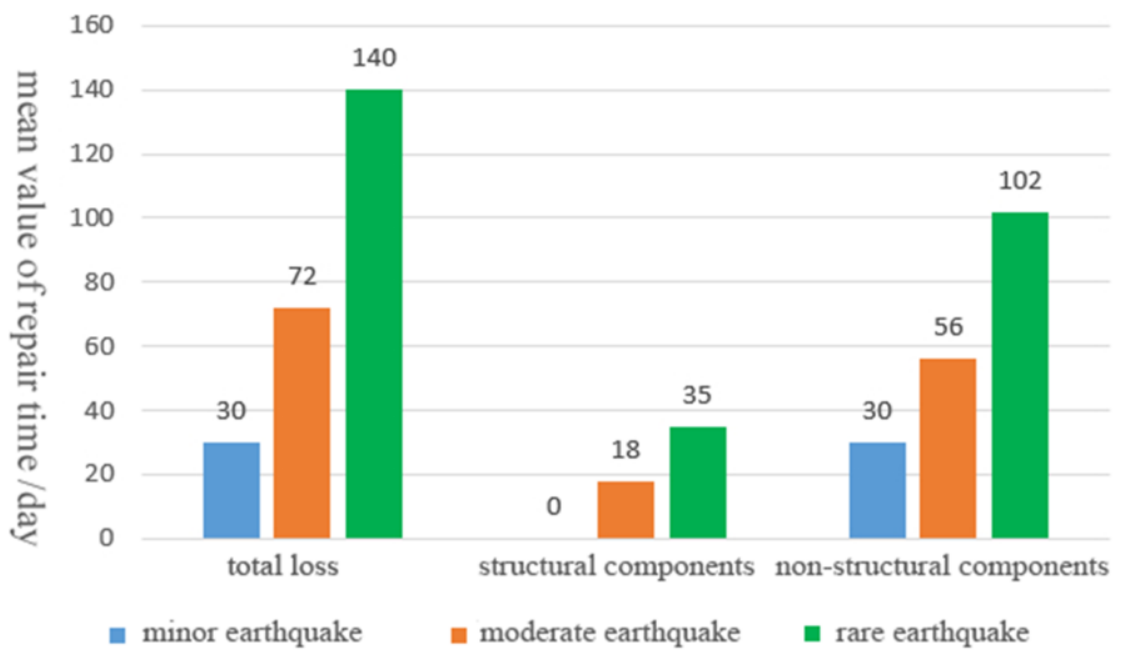

Figure 14. Mean value of repair time under different earthquake intensities of Building A. 


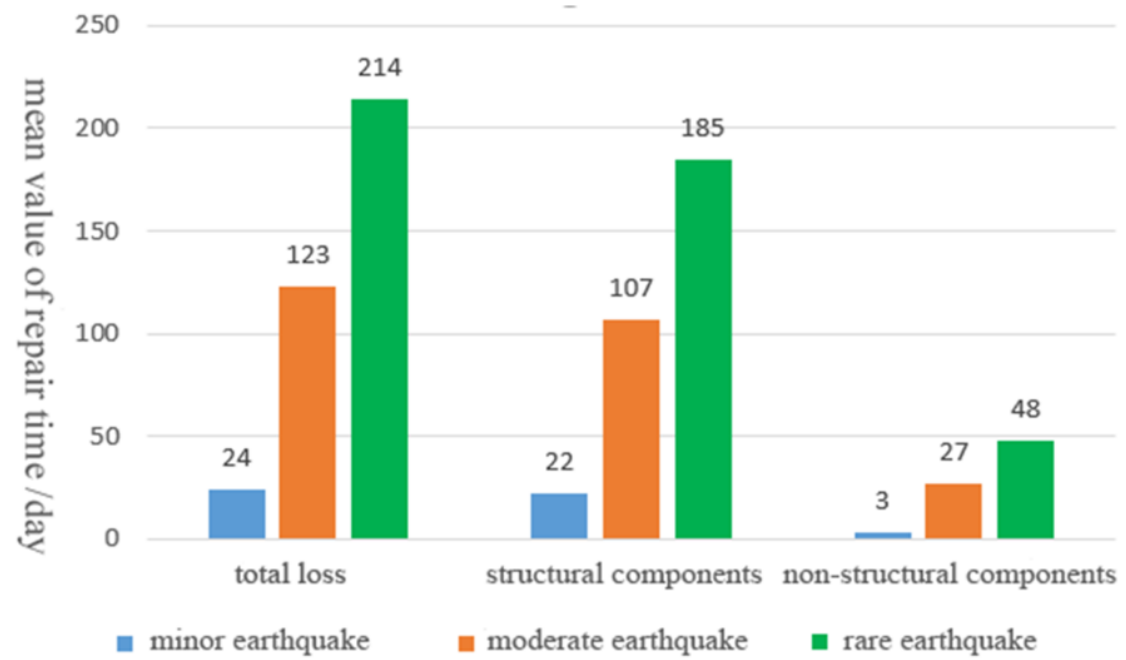

Figure 15. Mean value of repair time under different earthquake intensities of Building B.

The mean value of casualties under different earthquakes of the two buildings is shown in table 5. No casualties will occur in either building under minor earthquake; Under moderate earthquake, there will be still no casualties in building A and there is a possibility of death in building B; The number of casualties in building B will increase significantly under rare earthquake. The main vulnerability groups in the two buildings that may cause casualties are ceilings, staircases and elevators of non-structural components. Therefore, through reasonable structural design, the collapse of the structure can be avoided. And if the ceilings and other easy-to-fall components are well anchored and reliable measures are taken to protect the safety of staircases and elevators when earthquake happens, casualties caused by earthquakes can be effectively reduced.

Table 5. Casualties of the two buildings under different earthquakes.

\begin{tabular}{cccc}
\hline Earthquake intensity & Item & Building A & Building B \\
\hline \multirow{2}{*}{ Minor earthquake } & Number of injured & 0 & 0 \\
& Number of death & 0 & 0 \\
Moderate earthquake & Number of injured & 0 & 1.6 \\
& Number of death & 0 & 0.95 \\
\multirow{2}{*}{ Major earthquake } & Number of injured & 0.01 & 14 \\
& Number of death & 0 & 4 \\
\hline
\end{tabular}

\subsection{Evaluation Of Seismic Resilience}

Since the evaluation criterion of the Redi system is defined under the earthquake intensity of $10 \%$ exceedance probability in 50 years, therefore the seismic loss result of the building under moderate earthquake is used. The mean value of repair cost for Building A and Building B is $\$ 281,200$ and \$657,200, representing 20\% and 2.4\% of the reset cost of the building, respectively. According to the FEMA P-58 report on the population model for office and residential buildings, the peak daily population for buildings A and B is 199 and 105.4. 
In order to evaluate the seismic resilience, it is necessary to calculate the downtime for the restoration to the state of reuse and functional recovery of the building. Based on the repair time in FEAM P-58, the Redi system optimizes the repair sequence and labor allocation of components. It is assumed that all the components are Class 2 repair components, that is, all the functions can be restored only by replacing and maintaining the components. With the maximum number of workers (1 person $/ 2000$ sq.ft) assigned to each floor and the construction carried out in accordance with the recommended construction sequence (figure 16), the restoration time for building A and B to be restored to the state of reuse can be 8 days and 94 days respectively and the restoration time to functional recovery can be 54 days and 116 days respectively.

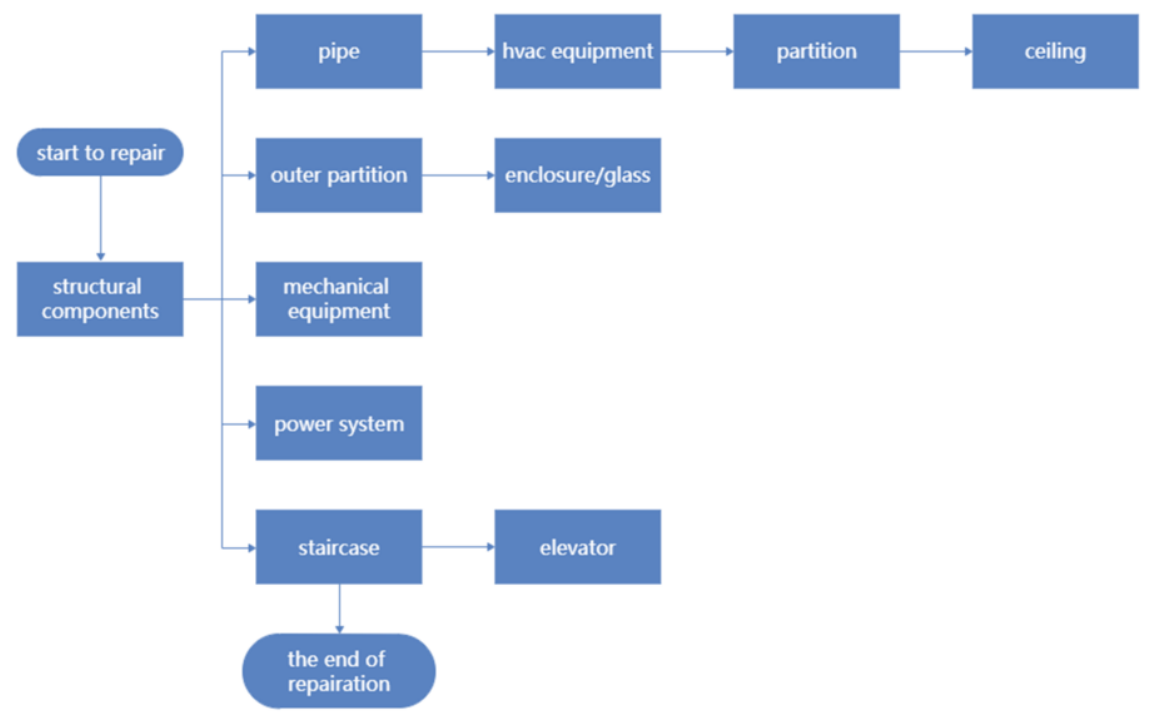

Figure 16. Optimized maintenance sequence of components in Redi system.

In addition to repair time, the downtime of buildings also includes the time during which impediments lead to the initiation or delay of maintenance elements, which may increase the actual downtime. In the Redi system, logarithmic normal distribution function is used to describe the barrier function. Considering the parameter dispersion caused by the real influence, the mean value of the obstacle function is taken to calculate, as shown in table 6. According to the occurrence sequence of obstructive factors (figure 17), the delay of downtime due to obstructive factors for Building A and Building B was calculated as 47 days and 26 days respectively. 


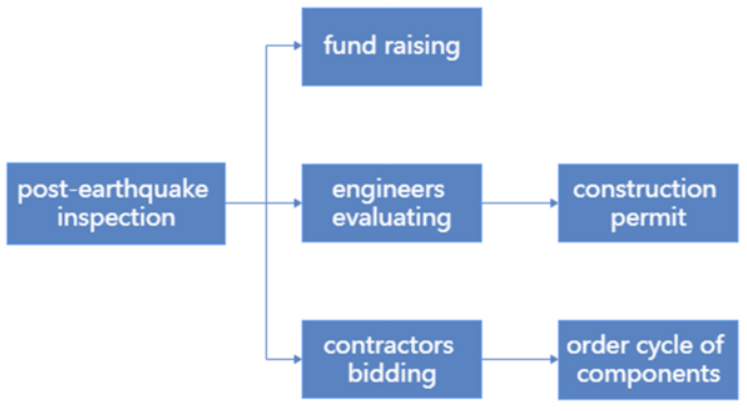

Figure 17. Delay sequence due to obstructive factors.

Table 6. The delay of downtime due to obstructive factors.

\begin{tabular}{|c|c|c|c|c|}
\hline \multirow[b]{2}{*}{ Obstructive factor } & \multicolumn{2}{|c|}{ Building A } & \multicolumn{2}{|c|}{ Building B } \\
\hline & $\begin{array}{l}\text { Obstruction } \\
\text { curve }\end{array}$ & $\begin{array}{l}\text { Mean value } \\
\text { of delay }\end{array}$ & $\begin{array}{l}\text { Obstruction } \\
\text { curve }\end{array}$ & $\begin{array}{c}\text { Mean value } \\
\text { of delay }\end{array}$ \\
\hline $\begin{array}{l}\text { Post-earthquake } \\
\text { inspection }\end{array}$ & $\begin{array}{l}\text { Non-essential } \\
\text { facilities }\end{array}$ & 5 days & $\begin{array}{l}\text { Non-essential } \\
\text { facilities }\end{array}$ & 5 days \\
\hline $\begin{array}{l}\text { Engineers } \\
\text { evaluating }\end{array}$ & $\begin{array}{c}\text { Structure repair } \\
\text { grade } 1\end{array}$ & 2 weeks & $\begin{array}{l}\text { Structure repair } \\
\text { grade } 3\end{array}$ & 4 weeks \\
\hline Fund raising & Reserve fund & 1 week & Reserve fund & 1 week \\
\hline Bidding & $\begin{array}{l}\text { Structure repair } \\
\text { grade } 1\end{array}$ & 3 weeks & $\begin{array}{l}\text { Structure repair } \\
\text { grade } 3\end{array}$ & 7 weeks \\
\hline $\begin{array}{l}\text { Construction } \\
\text { permit }\end{array}$ & $\begin{array}{l}\text { Structure repair } \\
\text { grade } 1\end{array}$ & 3 weeks & $\begin{array}{l}\text { Structure repair } \\
\text { grade } 3\end{array}$ & 3 weeks \\
\hline $\begin{array}{l}\text { Order cycle of } \\
\text { components }\end{array}$ & None & 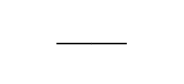 & None & 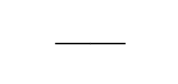 \\
\hline $\begin{array}{l}\text { Interruption of } \\
\text { public utilities }\end{array}$ & -1 & 10 days & 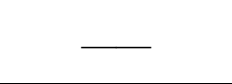 & 10 days \\
\hline
\end{tabular}

To sum up, based on the calculation method of downtime of Redi system, the downtime for building A and B to be restored to the state of re-use is 44 days and 151 days respectively and that for functional restoration is 90 days and 173 days respectively. In combination with the table of direct economic losses and casualties caused by the earthquake, Building A has a recovery rating of silver according to the rating requirements in table 1, while Building $B$ has no rating, as shown in table 7.

Table 7. Seismic resilience evaluation result of the example buildings.

\begin{tabular}{cccccc}
\hline $\begin{array}{c}\text { Name of } \\
\text { building }\end{array}$ & $\begin{array}{c}\text { Downtime for } \\
\text { re-occupancy }\end{array}$ & $\begin{array}{c}\text { Downtime for } \\
\text { functional } \\
\text { restoration }\end{array}$ & $\begin{array}{c}\text { Economic } \\
\text { loss rate }\end{array}$ & $\begin{array}{c}\text { Death } \\
\text { rate }\end{array}$ & $\begin{array}{c}\text { Resilience } \\
\text { rating }\end{array}$ \\
\hline $\begin{array}{c}\text { Building } \\
\text { A }\end{array}$ & 44 days & 90 days & $2.4 \%$ & $0 \%$ & Silver \\
$\begin{array}{c}\text { Building } \\
\text { B }\end{array}$ & 151 days & 173 days & $20 \%$ & $1.52 \%$ & None \\
\hline
\end{tabular}




\section{Conclusion}

Based on FEMA P-58 building loss assessment method and Redi architecture recoverability evaluation system, the seismic resilience evaluation method of urban buildings is proposed in this paper, and two typical urban structures are taken as examples to illustrate the evaluation process. The specific conclusions are as follows:

1) The multi-degree of freedom lumped-mass shear model and dynamic analysis can be used to quickly obtain the building demand parameters and vulnerability performance required for seismic resilience evaluation, so as to establish the building performance model.

2) In Redi, the repair time of buildings based on downtime takes into account the influence of possible obstructive factors such as the interruption of public utilities, which is more reasonable than the repair time of FEMA-P58.

3) The seismic resilience evaluation method based on FEMA P58 report and Redi can predict the detailed economic loss and casualties of buildings after an earthquake, and estimate the repair time to restore to a specific state, which can provide data bases for disaster prevention planning and resilient city construction for decision makers.

\section{Acknowledgments}

This work was supported by the National Key Research and Development Program of China (nos. 2016YFC0800209 and 2017YFC0803300) and the National Natural Science Foundation of China (no. 51178351).

\section{References}

[1] China Academy of Building Research 2010 Code for Seismic Design of Buildings

[2] Sino-Japanese Inspection Group 2012 Inspection report of the disaster of the East Japan earthquake by Sino-Japanese joint mission Building structure 42(4) pp 1-20

[3] Hongjo Y 2012 Summary of Damags from and Reconstruction Measures for Great East Japan Earthquake (Kobe: Kobe Institute of Urban Research)

[4] Peer 20162016 PEER Annual Meeting (CA: Berkeley)

[5] 2nd Int. Workshop on Resilience 2018 (China: Nanjing and Shanghai)

[6] Jiang H, Lv X and Quan L 2017 Research trend of earthquake resilient structures seen from 16WCEE Earthquake Engineering and Engineering Dynamics 3(37) pp 1-9

[7] Fema 2012 Seismic Performance Assessment of Buildings-Methodology vol 1 (Washington D C: Federal Emergency Management Agency)

[8] Fema 2012 Seismic Performance Assessment of Buildings-Implementation Guide vol 2 (Washington D C: Federal Emergency Management Agency)

[9] Arup 2013 Resilience-based Earthquake Design Initiative for the Next Generation of Buildings Version 1.0

[10] Almufti I and Willford M 2014 The Redi ${ }^{\mathrm{TM}}$ rating system: a framework to implement resilience-based earthquake design for new buildings (Alaska: Anchorage)

[11] Shanghai Earthquake Administration 2004 Shanghai Seismic Parameter Zoning (Shanghai: Earthquake Press)

[12] Shanghai Construction Materials Market Management Station 2013 Codes for Sseismic Design of Buildings in Shanghai (Shanghai: Shanghai Construction Materials Market Management Station)

[13] Center P 2018 PEER Ground Motion Database

[14] Nied 2018 Strong-motion Seismograph Network

[15] Xu Z, Lu X and Guan H 2014 Seismic damage simulation in urban areas based on a high-fidelity structural model and a physics engine Natural Hazards 71(3) pp1679-93 
1080 Y. Zhai et al. / Seismic Resilience Evaluation of Urban Buildings Based on FEMA-P58 and Redi

[16] Zeng X, Lu X, Yang T and Xu Z 2016 Application of the FEMA-P58 Methodology for Regional Earthquake Loss Prediction Natural Hazards 83(1) pp 177-92 